\title{
Variability of mesozooplankton biomass and individual size in a coast-offshore transect in the Catalan Sea: relationships with chlorophyll $a$ and hydrographic features
}

\author{
Miquel Alcaraz ${ }^{1}$, Albert Calbet ${ }^{1}$, Stamatina Isari ${ }^{1,2}$, Xabier Irigoien ${ }^{2}$, Isabel Trepat ${ }^{1}$, Enric Saiz ${ }^{1}$ \\ ${ }^{1}$ Institut de Ciències del Mar, CSIC, P. Marítim de la Barceloneta 37-49, 08003 Barcelona, Spain. \\ E-mail: miquel@icm.csic.es \\ ${ }^{2}$ King Abdullah University of Science and Technology, Red Sea Research Centre, Thuwal 23955-6900, \\ Kingdom of Saudi Arabia.
}

\begin{abstract}
Summary: The temporal and spatial changes of zooplankton and chlorophyll $a$ concentration were studied during the warm stratification period (early June) at three stations whose traits corresponded to the coastal, frontal, and offshore-dome water conditions described for the Catalan Sea. We sampled the stations for 12 days at a frequency ranging from less than 10 to $10^{2} \mathrm{~h}$, with a spatial resolution ranging from 10 to $10^{4} \mathrm{~m}$. The objective was to determine the variability of mesozooplankton and phytoplankton (chlorophyll $a$ ) biomass, and average individual size (mass) across a coast-offshore transect in relation to the stratification conditions prevailing in the NW Mediterranean during summer. The vertical distribution of phytoplankton biomass displayed a clear deep maximum at $60 \mathrm{~m}$ depth except at the coastal station. This maximum exists during most of the year and is especially important during the density stratification period. It was accompanied during daylight hours by a coherent zooplankton maximum. At sunset mesozooplankton ascended and dispersed, with larger organisms from deeper layers joining the migrating community and increasing the average individual mass. The highest variability of mesozooplankton biomass, individual mass and chlorophyll $a$ concentration occurred at the front station due to the coupling between the vertical migration of zooplankton and the particular characteristics of the front. According to the data shown, the highest variability was observed at the lowest scales.
\end{abstract}

Keywords: zooplankton biomass; NW Mediterranean; spatial distribution; short-term variability.

Variabilidad de la biomasa del zooplankton y de su tamaño individual en un transecto costa-alta mar en el ar Catalán: relaciones con la clorofila $a$ y las estructuras hidrográficas

Resumen: Durante el periodo de estratificación térmica (principios de junio) se estudiaron los cambios temporales y espaciales de concentración de zooplancton y clorofila $a$ en tres estaciones cuyos rasgos corresponden a las condiciones de aguas costeras, frontal y domo central descritas para el Mar Catalán. Muestreamos las estaciones a lo largo de 12 días con una frecuencia que varió entre $<10 \mathrm{~h} \mathrm{y} 10^{2} \mathrm{~h}$, y con una resolución espacial entre 10 y $10^{4} \mathrm{~m}$. El objetivo fue determinar la variabilidad de la biomasa del fitoplancton (clorofila $a$ ) y del mesozooplancton, así como de su tamaño individual promedio a lo largo de un transecto costa-mar abierto en relación con las condiciones de estratificación térmica típicas del Mediterráneo del Noroccidental desde finales de primavera a finales de verano. La distribución vertical de la biomasa de fitoplancton mostró la existencia de un máximo profundo a $60 \mathrm{~m}$ de profundidad, excepto en la estación costera. Aunque cierta heterogeneidad vertical en la biomasa de fitoplancton suele observarse durante la mayor parte del año, es especialmente importante durante el período de estratificación de densidad. El máximo de fitoplancton estuvo acompañado durante las horas de luz por un máximo de zooplancton, que en la crepúsculo ascendía y se dispersaba, y al que se unían organismos de mayor tamaño procedentes de zonas más profundas, contribuyendo a aumentar la masa individual promedio. La mayor variabilidad de biomasa mesozooplanctónica, de la masa individual y de la concentración de clorofila $a$ se observó en la estación frontal debido al acoplamiento entre la migración vertical del zooplancton y las características particulares del frente. Según los datos presentados la mayor variabilidad fue observada en las escalas espaciales y temporales más bajas.

Palabras clave: biomasa de zooplankton; Mediterráneo noroccidental; distribución espacial; variabilidad de corto plazo.

Citation/Como citar este artículo: Alcaraz M., Calbet A., Isari S., Irigoien X., Trepat I., Saiz E. 2016. Variability of mesozooplankton biomass and individual size in a coast-offshore transect in the Catalan Sea: relationships with chlorophyll $a$ and hydrographic features. Sci. Mar. 80S1: 79-87. doi: http://dx.doi.org/10.3989/scimar.04353.15A

Editor: D. Vaqué.

Received: October 1, 2015. Accepted: February 25, 2016. Published: September 30, 2016.

Copyright: () 2016 CSIC. This is an open-access article distributed under the terms of the Creative Commons Attribution (CC-by) Spain 3.0 License. 


\section{INTRODUCTION}

The study of the effects of physical singularities (i.e., mesoscale features and density stratification) on the characterisitics of plankton distribution, structure and function in the Catalan Sea started about four decades ago, in the framework of a series of research projects led by Dr Marta Estrada (see Marta Estrada bibliography in this volume). The projects merged different research groups of the former Instituto de Investigaciones Pesqueras (Institute of Fishery Research of Barcelona, now the Marine Sciences Institute) and the University of Barcelona, and received the invaluable advice and participation of Prof. Ramon Margalef. The area has thus been the object of successive studies almost unenterrumptedly, and this paper is a late consequence of one of them.

A better understanding of the role of zooplankton in food web dynamics and carbon balance in pelagic systems requires not only simultaneous estimates of the structural parameters and metabolic rates, but also to characterize their reliability in relation to the spatial and temporal scales considered. While rate processes seem to exhibit fast responses to physical or biological external forcing (Alcaraz 1988, Calbet et al. 1996), extensive properties such as biomass and taxonomic composition are considered to follow more gradual changes through cumulative processes (i.e. growth and reproduction, Alcaraz et al. 2007). However, their rate of change depends not only on demographic parameters. Behavioural characteristics of zooplankton and advection processes strongly determine their patchy nature and therefore the limits of what can be accepted as synoptic in terms of data representativeness and ecosystem dynamics (Steele and Henderson 1992).

In Stommel's classic diagram about the time-spaceintensity scales of variability in plankton, and of the factors contributing to them (Stommel 1963, Haury et al. 1978, Vance and Doel 2010), frequency and intensity of changes are inversely related. However, at the highest frequencies (small-scale variability) the magnitude of the changes is by no means negligible. Physical, chemical and social patterns (Stavn 1971), coupled with the effects of size and nature of patch formation and diffusion, among other parameters, impose severe limits on the acquisition of synoptic information of plankton structures (Longhurst et al. 1966, Haury $1976 a, b)$. As a matter of fact, the problem is reduced to assessing how far in time and space a particular zooplankton sample can be considered representative (Winsor and Clarke 1940). In most cases, part of the variability derived from predictable sources such as tidal currents and light-induced activity rhythms can be avoided or at least significantly reduced by adopting suitable sampling strategies. However, as pointed out by Haury et al. (1978): "...if the trade-off is between economics, impatience and ecological convenience, usually impatience and economics win".

In the NW Mediterranean, organismal behaviour and physical heterogeneity are important as variability sources, specifically for zooplankton (Pinot and Jansá 2001). A sub-surface maximum of phytoplankton productivity and biomass occurs most of the year (Estrada 1985) and is especially strong during the summer stratification period. This deep phytoplankton biomass and production layer is usually accompanied by a zooplankton biomass maximum (Alcaraz 1985, 1988, Alcaraz et al. 2010). Although the zooplankton biomass contributes a significant proportion of the short-term temporal and spatial variability due to the daily vertical migration of the organisms (Alcaraz 1985, Saiz and Alcaraz 1990, Alcaraz et al. 2010), highly dynamic hydrographic structures such as density fronts could be further sources of daily and seasonal zooplankton changes (Boucher et al. 1987, Fernández de Puelles et al. 2004, Mazzocchi et al. 2014).

The main objective of the Spanish research project VARIMED (AMB94-1019) was to improve our understanding of the matter and energy flux and carbon balance in the pelagic domain in the Catalan Sea (NW Mediterranean). To this end, we studied the short-term changes in the structural properties and rate processes for the different plankton components, from bacteria and phytoplankton (Acinas et al. 1997, Estrada 1996, Agawin and Agustí 1997) to zoooplankton and seabirds (Saiz et al. 1997, Abelló and Oro 1998). In this paper the variability in time and space scales ranging from hours to weeks and from metres to tens of kilometres of the structural properties of zooplankton is analysed in relation to phytoplankton (chlorophyll $a$, hereafter Chl $a$ ) and the physical characteristics of coastal-frontaloffshore conditions in a transect in the Catalan Sea. Accordingly, the two main objectives were: 1 ) to determine the variability pattern of biomass and size (individual mass) of zooplankton at the beginning of the summer stratification period, and 2) to estimate the possible interaction between the physical and biological ( $\mathrm{Chl} a$ ) and the space and time variability patterns observed.

\section{METHODOLOGY}

The study took place in the Catalan Sea (NW Mediterranean) during the oceanographic cruise VARIMED-95 (2-14 June 1995) on board the R/V Hespérides. The study was done in a $120-\mathrm{km}$ transect approximately perpendicular to the coastline (Fig. 1), running from Barcelona to the middle of the Majorca-Menorca channel. This transect had been systematically sampled in previous oceanographic cruises (for a complete list, see Alcaraz et al. 2007).

Three structures of different characteristics define the hydrography and ecological peculiarities of the Catalan Sea (Font et al. 1988, Salat 1996, Alcaraz et al. 2007): the coastal zone, influenced by waters of continental origin, with an outer current running NESW parallel to the coast, the Liguro-Provençal-Catalan Current; the Catalan density front at the outer margin of the current, usually occluded during the summer stratification period but clearly marked below the thermocline; and a dome-like structure in the central part of the Catalan-Balearic Sea (Alcaraz 1988, Estrada and Margalef 1988). These structures are corresponding analogues of those described for the Nice-Calvi transect by Boucher (1984). 


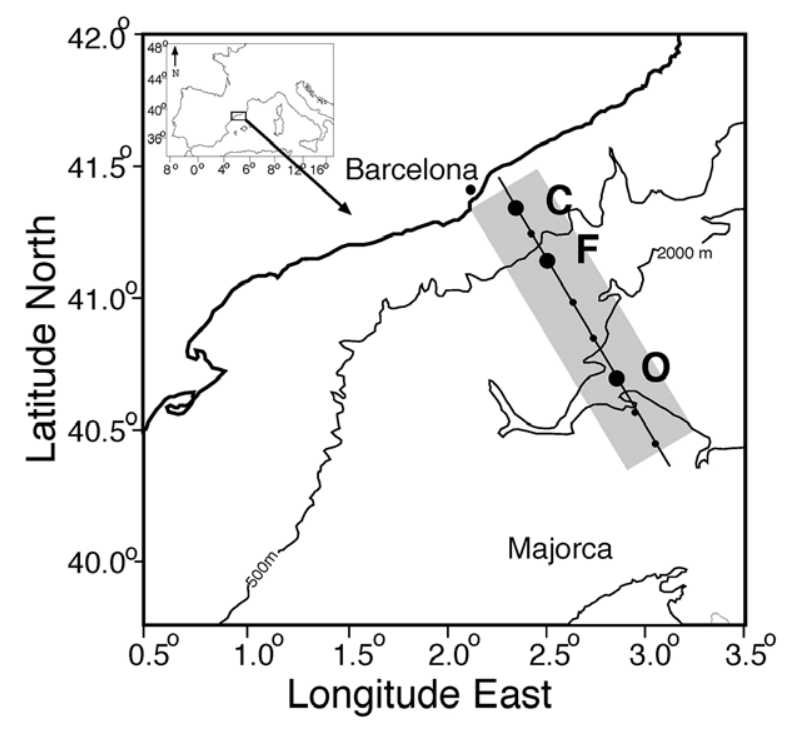

Fig. 1. - Map of the study area with the position of the hydrographic stations in the $120 \mathrm{~km}$ transect between Barcelona and the MajorcaMenorca channel (dots). Large black dots: coastal (C), frontal (F) and offshore $(\mathrm{O})$ stations. Shaded rectangle: area occupied by the grid of CTD casts made to characterize the area hydrographically.

\section{Sampling strategy}

Previous to the biological study, we obtained quasisynoptic information on the hydrography of the area (temperature, salinity and fluorescence profiles) with a Neil-Brown MARK-V CTD provided with a fluorometer, in a grid of stations (shaded rectangle in Fig. 1) including the study stations. According to the physical characteristics and $\mathrm{Chl} a$ distribution pattern, three biological stations were chosen as representative of the above-mentioned coastal, frontal and offshore conditions (hereafter $\mathrm{C}\left(41^{\circ} 20^{\prime} \mathrm{N}, 2^{\circ} 17^{\prime} \mathrm{E}\right), \mathrm{F}\left(41^{\circ} 07^{\prime} \mathrm{N}\right.$, $\left.2^{\circ} 27^{\prime} \mathrm{E}\right)$ and $\mathrm{O}\left(40^{\circ} 40^{\prime} \mathrm{N}, 2^{\circ} 53^{\prime} \mathrm{E}\right)$, located at $10,35.9$ and $89.4 \mathrm{~km}$ from the shore and above 80, 900 and $2000 \mathrm{~m}$ depth, respectively (big dots in Fig. 1).

The sampling schedule consisted of three visits (legs) to the three stations at regular intervals during a 12-day period (Table 1). Every 4 days, each station was sampled for $24 \mathrm{~h}$ at 4 - to 8 -h intervals, resulting from 3 to 5 zooplankton hauls per day, usually 1 to 2 during dusk or dawn hours, one at noon and 1 to 2 during the night. For Station $\mathrm{O}$ we had only partial samples on the first day due to a failure of the net. In total, we made 29 hauls (10 at Station C, 11 at Station F, 8 at Station O), completing 198 depth-strata samples. Between successive legs and on the way back to the first sampled station (Station O), we spent $24 \mathrm{~h}$ doing fast CTD casts along the transect in order to detect changes in the physical structure that would make it necessary to re-consider the geographic position of the stations.

\section{Chlorophyll concentration}

The vertical profiles of Chl $a$ concentration were obtained by relating the fluorescence at selected depths obtained with the fluorometer installed in the CTD to the Chl $a$ concentration analysed in water samples taken simultaneously at the depths of the corresponding fluorescence readings. Chl $a$ was analysed on board fluorimetrically in acetone extracts according to Yentsch and Menzel (1963). The equation relating Chl $a$ to fluorescence was $\mu \mathrm{g} \mathrm{Chl} a \mathrm{~L}^{-1}=0.132+14.26 \mathrm{Fl}$, $\mathrm{r}=0.88, \mathrm{n}=77$.

\section{Mesozooplankton}

After an initial CTD cast, according to the vertical structure of density and fluorescence, 6 to 8 depths intervals between 0 and either $60 \mathrm{~m}$ (St. C) or $100 \mathrm{~m}$ depth (Stations $\mathrm{F}$ and $\mathrm{O}$ ) were chosen depending on the station depth. The mesozooplankton samples were obtained by descending oblique net tows made with a LonghurstHardy Plankton Recorder ${ }^{\circledR}$ net (hereafter LHPR) fitted with $200 \mu \mathrm{m}$-mesh netting and equipped with a flowmeter and a Seabird ${ }^{\circledR}$ CTD. These tows provided data on temperature, salinity and in vivo fluorescence, as well as average, minimum and maximum depth interval, and filtered water volume $\left(\mathrm{m}^{3}\right)$ for each sampled depth interval. The water volume filtered for each depth interval ranged from 11.94 to $68.97 \mathrm{~m}^{3}$ (average $=34.86 \mathrm{~m}^{3}$, standard deviation $=15.67 \mathrm{~m}^{3}$ ). The zooplankton samples were preserved in formalin buffered with hexamethylene-tetramine to a final concentration of $4 \%$.

Mesozooplankton biomass as organic carbon (hereafter $\mathrm{C}_{\mathrm{ZOO}}$ ) was estimated after biovolume determinations by applying the corresponding conversion factor between mesozooplankton biovolume $\left(\mathrm{V}_{\mathrm{Z}}\right)$ and organic $\mathrm{C}$ contents for mixed zooplankton communities of the NW Mediterranean (Alcaraz et al. 2003). Sample $\mathrm{V}_{\mathrm{Z}}$ was estimated by integrating the volumes of individual organisms corresponding to sample aliquots after excluding macroplankton (a few jellyfish, salps and siphonophores) by screening the sample through a 1-cm-mesh plastic grid. Images of the fixed samples were obtained with an EDI CCD video camera installed in a stereomicroscope connected to a computer. The images were analysed with a semi-automatic free image analysis software (NIH-Image ${ }^{\circledR}$, National Institute of Health, Bethesda, Md., USA) that counted the individuals in the sample and measured the area contained by their silhouette, transforming it into an ellipse

Table 1. - Sampling schedule during the VARIMED-95 cruise. The grey shadowed columns correspond to days dedicated to obtaining quick hydrographic surveys along the transect shown in Figure 1. The black zones correspond to biological sampling, generally repeated four times per day: 1) early morning, from 6 to $8.30 \mathrm{~h}$; 2) midday, from 11.30 to $13.30 \mathrm{~h} ; 3$ ) evening, from $17 \mathrm{ho} 19 \mathrm{~h}$; 4) night, around $22 \mathrm{~h}$.

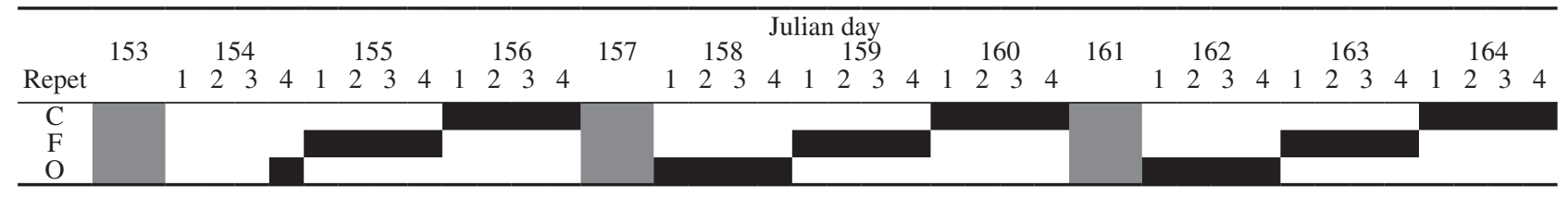



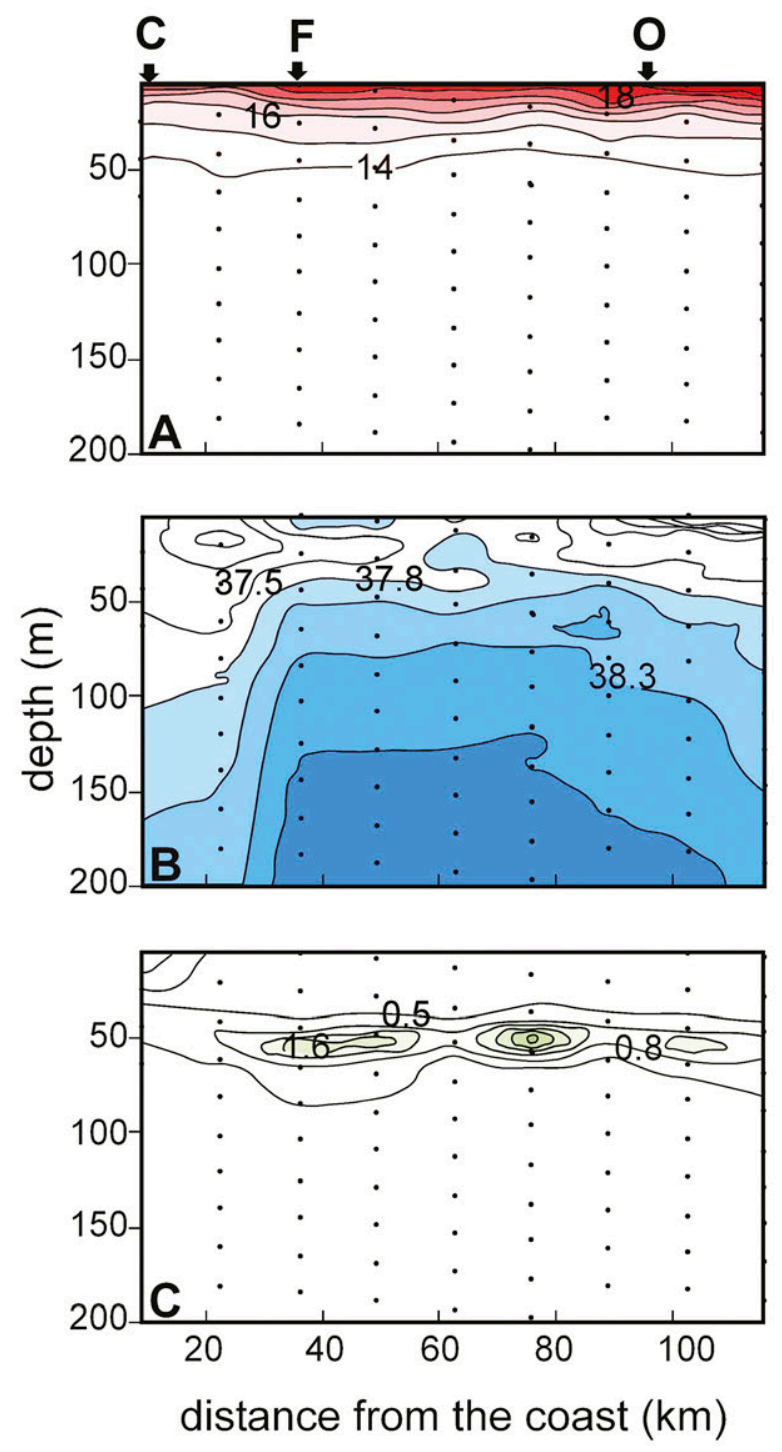

Fig. 2. - Distribution of temperature (A), salinity (B) and chlorophyll $a(\mathrm{C})$ from 0 to $100 \mathrm{~m}$ depth along the transect between Barcelona and the Majorca-Menorca channel during the first study day (JD 153). In the horizontal axis, the distance to the coast refers to Barcelona.

of the same area (Alcaraz et al. 2003). The volume of the organism was assimilated to that of the ellipsoid resulting from the rotation of the ellipse about its major axis. We used the $\mathrm{Z}_{\mathrm{V}-} \mathrm{C}_{\mathrm{ZOO}}$ transform factor given by Alcaraz et al. (2003) for formalin-preserved mixed zooplankton (gelatinous components excluded) of the western Mediterranean: $1 \mathrm{~mm}^{3} \mathrm{Z}_{\mathrm{V}}=0.078 \mathrm{mg} \mathrm{C}_{\mathrm{ZOO}}$.

Aliquots of the samples corresponding to the different depth intervals of each haul were analysed, the biomass being calculated according to the fraction of the sample analysed and the water volume filtered by the net along the depth stratum:

$$
\mathrm{C}_{\mathrm{ZOO}-\mathrm{i}}=\mathrm{C}_{\mathrm{ZOO}-\mathrm{a}}\left(\mathrm{F} \mathrm{V}_{\mathrm{i}}\right)^{-1}
$$

where $\mathrm{C}_{\mathrm{ZOO}-\mathrm{i}}$ is the averge biomass $\left(\mu \mathrm{gC}_{\mathrm{ZOO}} \mathrm{m}^{-3}\right)$ in the depth interval $\mathrm{I}, \mathrm{C}_{\mathrm{ZOO}-\mathrm{a}}$ is the biomass of the aliquot analysed, $\mathrm{F}$ is the fraction of the total sample corresponding to the analysed aliquot, and $\mathrm{V}_{\mathrm{i}}$ is the water
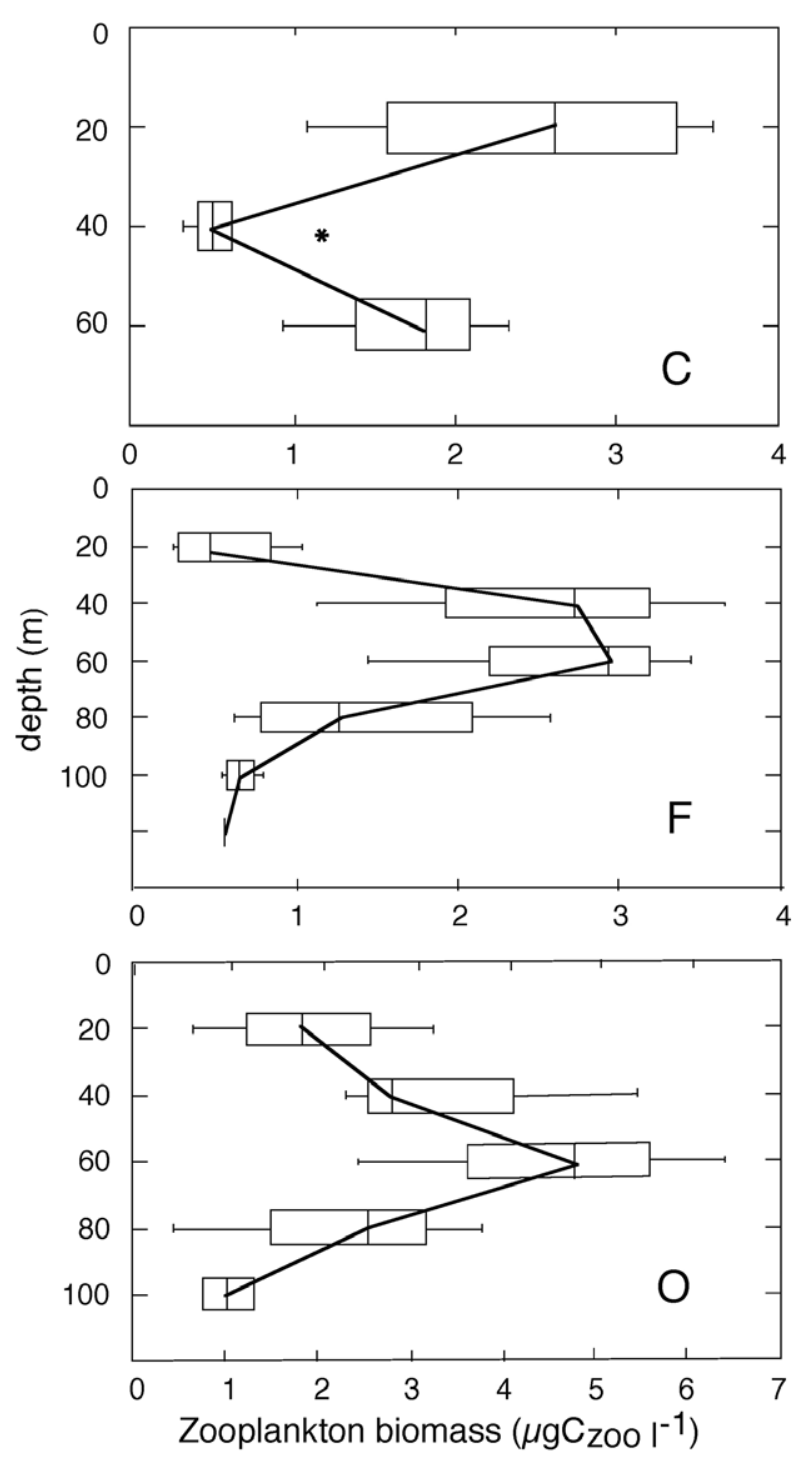

Fig. 3. - Box-plot of the average depth distribution of $\mathrm{C}_{\mathrm{ZOO}}(\mu \mathrm{gC}$ $\mathrm{L}^{-1}$ ). $\mathrm{C}, \mathrm{F}$ and $\mathrm{O}$ as in Figure 1. At Station $\mathrm{C}$ the maximum depth stratum sampled was $60 \mathrm{~m}$, as the station depth was only $80 \mathrm{~m}$. *: Outlier.

volume filtered by the net along the depth interval. For graphic and statistical purposes, the sampling depth of each interval was considered to be the average interval depth. The abundance of mesozooplankton in individuals $\mathrm{m}^{-3}$ (IND) was calculated similarly, as

$$
\mathrm{IND}_{-\mathrm{i}}=\mathrm{IND}_{-\mathrm{a}}\left(\mathrm{F} \mathrm{V}_{\mathrm{i}}\right)^{-1}
$$

where IND $_{-i}$ is the number of individuals corresponding to the depth interval I, IND -a $_{\text {a }}$ is the number of individuals in the aliquot analysed, and $F$ and $V_{i}$ are as in Equation 1.

The average zooplankton biomass for each haul was calculated as the integrated biomass for the whole haul divided by the haul depth,

$$
\mathrm{C}_{\text {ZOO-h }}=\left(\sum_{\mathrm{i}=1}^{\mathrm{n}}\left(\mathrm{C}_{\mathrm{ZOO}-\mathrm{i}}\left(\mathrm{Z}_{\mathrm{i}+1}-\mathrm{Z}_{\mathrm{i}}\right)\right)\right) \mathrm{Z}_{\mathrm{t}}^{-1}
$$


where $\mathrm{C}_{\mathrm{ZOO}-\mathrm{h}}$ is the average haul mesozooplankton biomass, $\mathrm{C}_{\mathrm{ZOO}-\mathrm{i}}$ is the average biomass in the layer $\mathrm{I}, \mathrm{Z}_{\mathrm{i}+1}$ and $Z_{i}$ are the lower and upper depths of the considered water layers, $Z_{t}$ is the total depth of the haul and $n$ is the total number of depth intervals sampled.

Average individual zooplankton biomass $\left(\mathrm{I}_{\mathrm{M}}\right)$ was calculated from the quotient between the average biomass and the average IND. $\mathrm{C}_{\mathrm{ZOO}}, \mathrm{I}_{\mathrm{M}}$ and IND are expressed in $\mu \mathrm{gC}_{\mathrm{ZOO}} \mathrm{L}^{-1}, \mu \mathrm{gC}$ ind ${ }^{-1}$ and individuals $\mathrm{m}^{-3}$, respectively. The variability was calculated as the coefficient of variation $\mathrm{CV}=100(\sigma / \mu)$. Statistical analyses were made using the $\mathrm{JMP}^{\circledR}$ software for Macintosh, the graphs about average depth distribution of mesozooplankton biomass $\left(\mathrm{C}_{\mathrm{ZOO}}\right)$ using Systat ${ }^{\circledR}$ statistical and graphical software, and the mapping of the variables with the Surfer ${ }^{\circledR}$ software for PC.

\section{RESULTS}

\section{Hydrography and chlorophyll $a$}

The hydrographic structure along the transect corresponded to the typical thermal stratification situation

\section{$\mathrm{Chl} \mathrm{a}\left(\mu \mathrm{g} \mathrm{L} \mathrm{L}^{-1}\right)$}
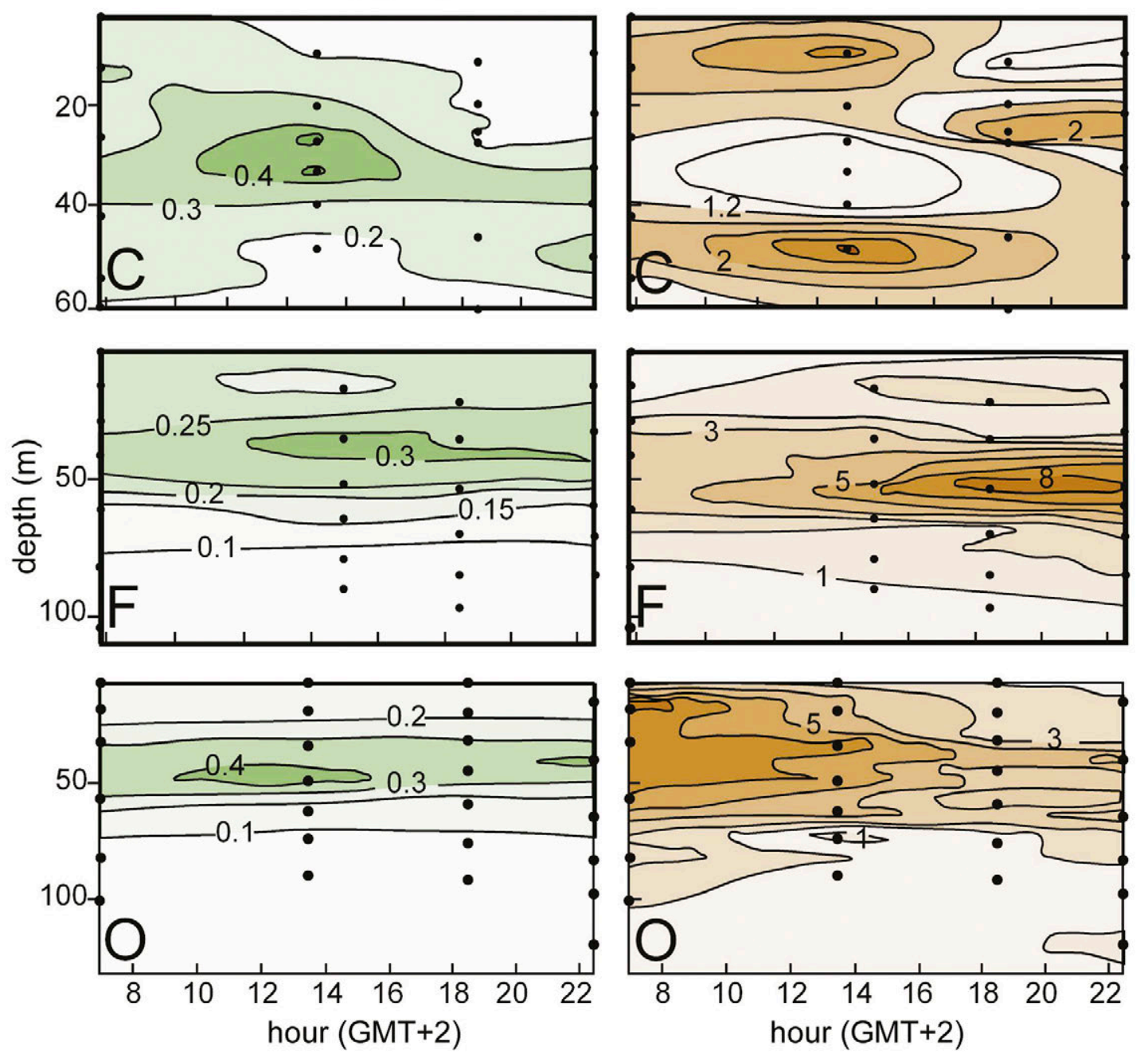

Fig. 4. - Chl $a$ and $\mathrm{C}_{\mathrm{ZOO}}$ depth distribution at noon along a $24 \mathrm{~h}$ series for one of the legs (JD 162-164). The trends were similar for legs JD 154-156 and JD158-160. Horizontal axis, GMT+2; vertical axis, depth in m. C, F and O as in Figure 1.

( $\mathrm{C}_{\mathrm{ZOO}}\left(\mu \mathrm{g} \mathrm{C} \mathrm{L} \mathrm{L}^{-1}\right), \mathrm{I}_{\mathrm{M}}\left(\mu \mathrm{g} \mathrm{C}\right.$ ind. ${ }^{-1}$ ) and IND (individuals $\mathrm{m}^{-3}$ ) at coastal $(\mathrm{C})$, frontal $(\mathrm{F})$ and offshore $(\mathrm{O})$ stations. The time- and space grations). Station C, 10 hauls, 63 depth strata; Station F, 11 hauls, 75 depth strata; Station O, 8 hauls, 60 depth strata.

\begin{tabular}{lccc}
\hline Variable & $\mathrm{C}$ & $\mathrm{F}$ & $\mathrm{O}$ \\
\hline $\mathrm{C}_{\text {ZOO }}$ & $1.34(39)$ & $1.81(61)$ & $2.19(31)$ \\
$\mathrm{IM}$ & $7.29(43)$ & $11.06(62)$ & $8.46(32)$ \\
IND & $370(74)$ & $533(97)$ & $696(65)$ \\
\hline
\end{tabular}

of late spring-early summer in the NW Mediterranean (Estrada 1985, Estrada and Margalef 1988, Saiz and Alcaraz 1990), with the signature of the front occluded at surface by the mixing layer above the thermocline. However, the position of the front was identifiable at depth by the salinity and density gradients (Fig. 2). The deep chlorophyll layer (DCL) was well developed below the thermocline at around $60 \mathrm{~m}$ depth, except at the coast (station $\mathrm{C}$ ), where in addition to the deep layer a surface maximum was visible (Fig. 2). The DCL was a persistent structure, the maximum concentration of Chl $a$ increasing with the distance from the coast from 0.8 to $1.8 \mu \mathrm{g} \mathrm{Chl} a \mathrm{~L}^{-1}$ (Fig. 2). During the 12 study

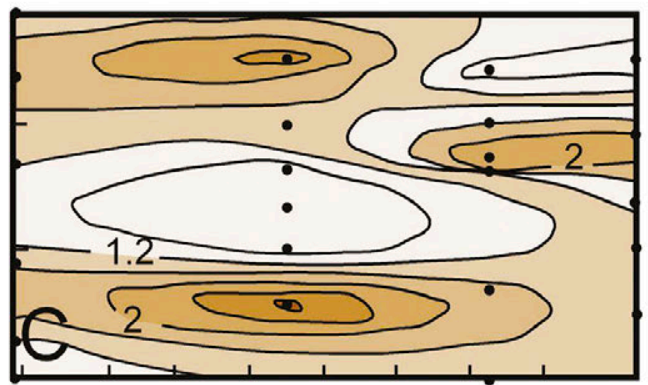




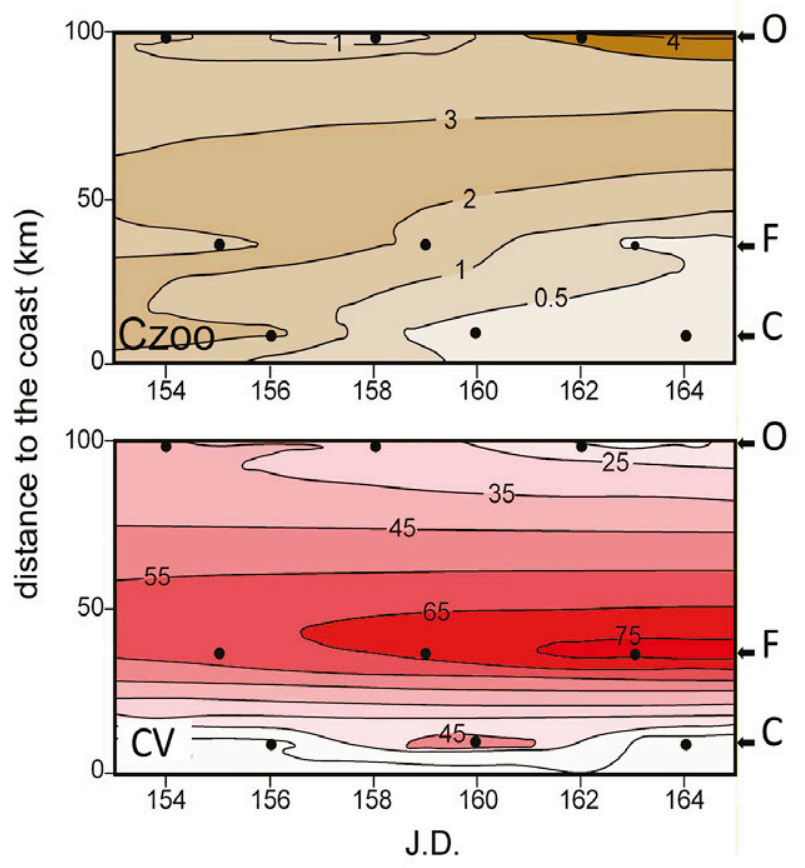

Fig. 5. - Depth-integrated average values of mixed day and night samples of mesozooplankton biomass $\left(\mathrm{C}_{\mathrm{ZOO}}\right)$ and its variability (CV) along the studied transect during the period analysed. Horizontal axis, sampling day (JD); vertical axis, distance from the coast $(\mathrm{km})$. The integrated depth was $60 \mathrm{~m}$ for Station $\mathrm{C}$ and $100 \mathrm{~m}$ for Stations $\mathrm{F}$ and $\mathrm{O}$.

days, according to the three fast hydrographic surveys made along the transect (the initial one on Julian day [JD] 153 plus two between legs, JD 157 and 161, respectively), there were no significant changes in the physical structure of the study area (i.e. temperature or salinity profiles), in the position of the front, or in the depth of the DCL.

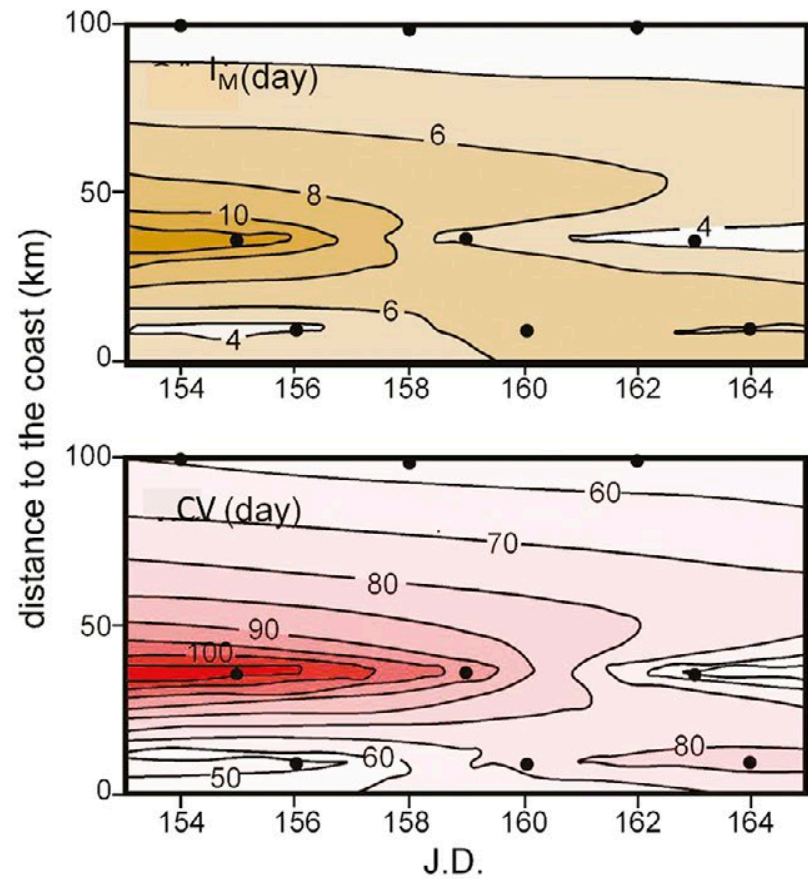

\section{$\mathrm{C}_{\mathrm{ZOO}}, \mathrm{I}_{\mathrm{M}}$ and IND}

The vertical distribution of $\mathrm{C}_{\mathrm{ZOO}}$ showed a maximum around $60 \mathrm{~m}$ depth (noon samples) in association with the DCL at the base of the thermocline. This pattern was clear at Stations F and O, whereas at Station $\mathrm{C}$ the zooplankton maximum occurred at $20 \mathrm{~m}$ depth, with a minimum at $40 \mathrm{~m}$ and a new secondary maximum at $60 \mathrm{~m}$ depth (Fig. 3). Overall, the depthintegrated average $\mathrm{C}_{\mathrm{ZOO}}$ and IND for the three stations indicated a positive coast-offshore gradient, with the highest values offshore (Table 2). At time and space resolutions ranging from 4 to $6 \mathrm{~h}$ and from 10 to 20 $m$ depth, respectively (Fig. 4), the relative maximum of $\mathrm{C}_{\mathrm{ZOO}}$ was at around $60 \mathrm{~m}$ depth for noon samples, coinciding with the DCL (stations $\mathrm{F}$ and $\mathrm{O}$ ), while at Station $\mathrm{C}$ it was less conspicuous. $\mathrm{I}_{\mathrm{M}}$ appeared to be inversely related to $\mathrm{C}_{\mathrm{ZOO}}$ at Stations $\mathrm{C}$ and $\mathrm{F}$. At Station $\mathrm{O}$ the loss of part of the data made it impossible to confirm this observation.

In a space-time- $\mathrm{C}_{\mathrm{ZOO}}$ diagram (time-space scales: $10^{4} \mathrm{~m}$ and $10^{2} \mathrm{~h}$, respectively), the daily average $C_{\text {zoO }}$ followed the above-mentioned coast-offshore positive gradient, which was more visible in the final part of the cruise (Fig. 5). At the same time, for Stations $\mathrm{C}$ and $\mathrm{F}$ there was a decrease in $\mathrm{C}_{\mathrm{ZOO}}$ over time, while at Station $\mathrm{O}$ the tendency seemed to be the opposite. No significant changes were observed between day and night samples. The $\mathrm{I}_{\mathrm{M}}$ (Fig. 6) showed a tendency to decrease during the study in day samples, while the opposite pattern was observed in night samples, especially at Station F.

\section{Variability}

At the time and space scales of $10^{2} \mathrm{~h}$ and $10^{2} \mathrm{~m}$ (successive legs for a given station and for the whole
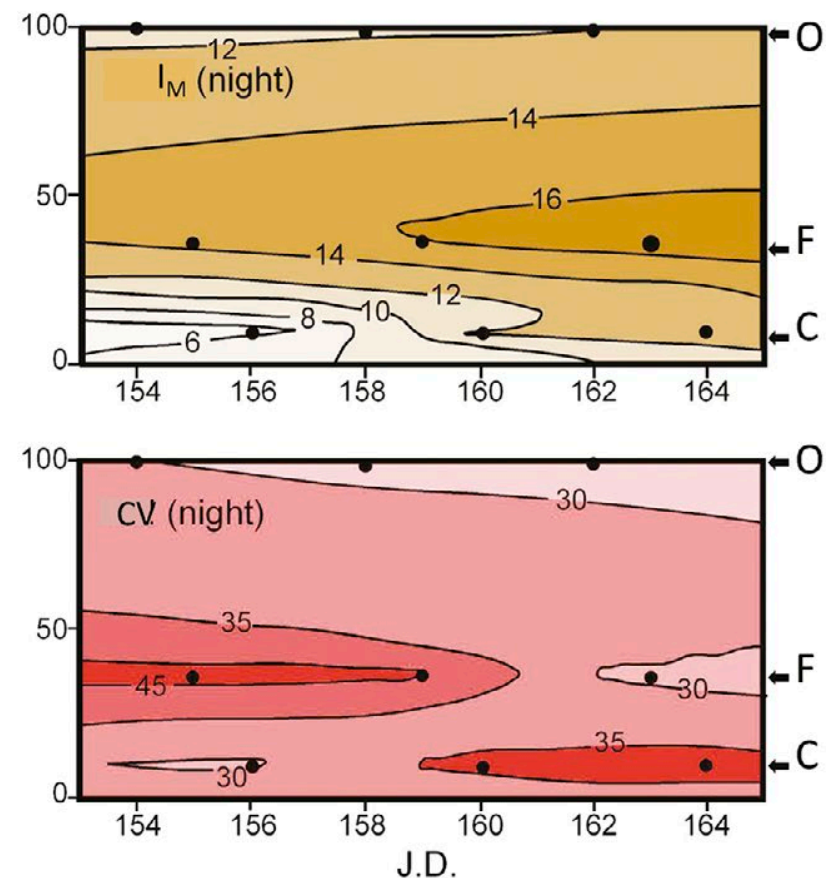

Fig. 6. - Average values of biomass $\left(\mathrm{C}_{\mathrm{ZOO}}\right)$ and individual size $\left(\mathrm{I}_{\mathrm{M}}\right)$ and their variability $(\mathrm{CV})$ for day and night samples. Horizontal and vertical axes as in Figure 5. 

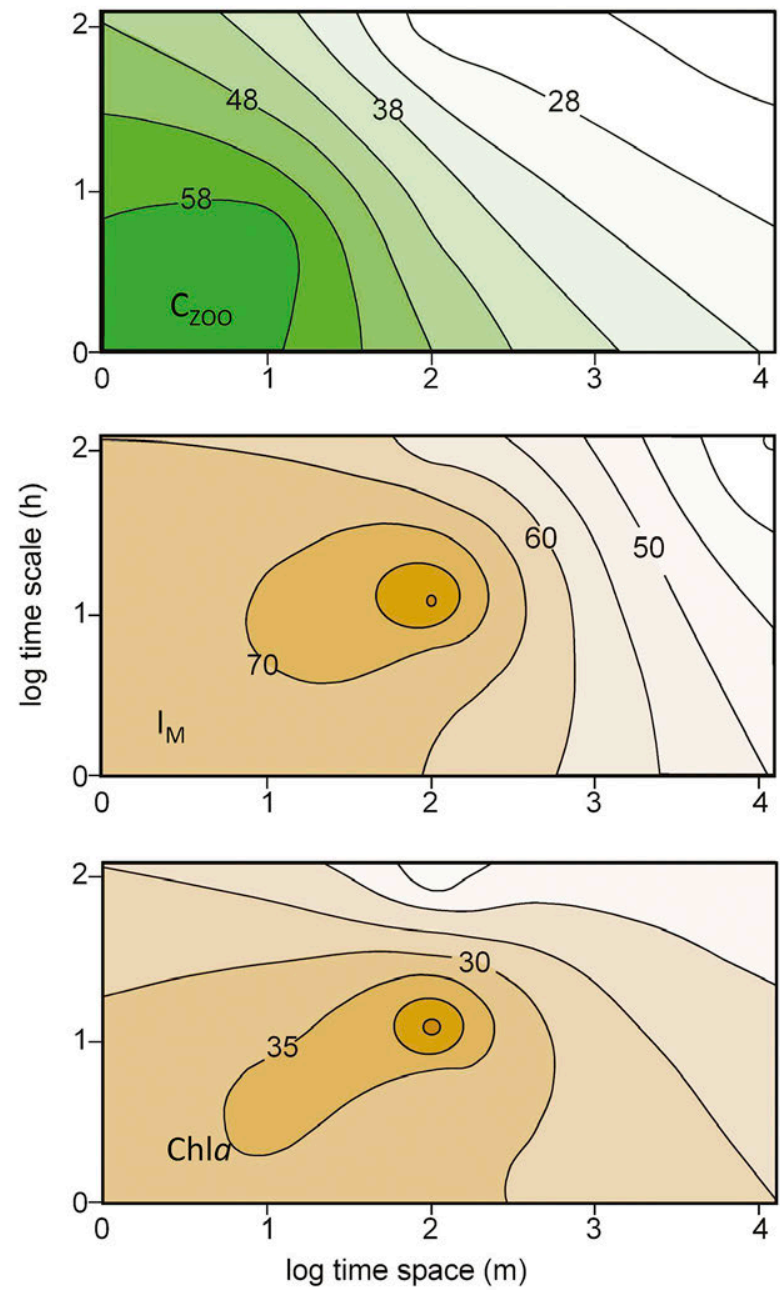

Fig. 7. - Contours of the variability $(\mathrm{CV})$ of $\mathrm{C}_{\mathrm{Z}}, \mathrm{I}_{\mathrm{M}}$, and $\mathrm{Chl} a$ at the spatial and temporal scales considered in the study, from $<10$ (depths strata) to $10^{4} \mathrm{~m}$ (between stations), and from $<10 \mathrm{~h}$ (between successive daily hauls) to $10^{2} \mathrm{~h}$ (between successive legs). Horizon-

tal axis, log space scale (m); vertical axis, log time scale (h).

0-100 m water column, respectively), the average values and variability of $\mathrm{C}_{\mathrm{ZOO}}, \mathrm{I}_{\mathrm{M}}$ and IND at Stations $\mathrm{C}, \mathrm{F}$ and $\mathrm{O}$ are indicated in Table 2 . The highest variability corresponded to Station $\mathrm{F}$ and the lowest to Station O).

Table 3 shows the variability of $\mathrm{C}_{\mathrm{ZOO}} \mathrm{I}_{\mathrm{M}}$ and $\mathrm{Chl}$ $a$ for all the time and space scales considered. The variability of $\mathrm{C}_{\mathrm{ZOO}}$ was inversely related to the time and space scales, with CVs ranging from $59(4-6 \mathrm{~h}, 10 \mathrm{~m})$ to $18\left(10^{2} \mathrm{~h}, 10^{4} \mathrm{~m}\right)$. IM showed a similar trend, but there was a significant increase in the $\mathrm{CV}$ to 81 at time scales coinciding with the day-night cycle (about $10 \mathrm{~h}, 10^{2} \mathrm{~m}$ ), and similar results were found for Chl $a(\mathrm{CV}=47)$.

In Figure 5, the time-space-variability diagram of zooplankton biomass indicates the higher variability associated with Station F $(\mathrm{CV}>60)$ and a tendency to increase towards the end of the cruise. The highest variability of $\mathrm{I}_{\mathrm{M}}$ was directly associated with the average individual size in daylight samples (Fig. 6), while during the night the tendency was the opposite.

The variability associated with the combined time and space scales included in the study for $\mathrm{C}_{\mathrm{ZOO}}, \mathrm{I}_{\mathrm{M}}$ and Chl $a$ is represented in Figure 7. According to this
Table 3. - Variability $(\mathrm{CV}, \%)$ of zooplankton biomass, $\mathrm{C}_{\mathrm{ZOO}}(\mu \mathrm{g} \mathrm{C}$ $\mathrm{L}^{-1}$ ), individual mass, $\mathrm{I}_{\mathrm{M}}$ ( $\mu \mathrm{g} \mathrm{C}$ ind.$^{-1}$ ), and Chl $a$, (ug chlorophyll $a$ $\left.\mathrm{L}^{-1}\right)$ at the time- and space scales explored during the survey.

\begin{tabular}{|c|c|c|c|c|}
\hline \multicolumn{2}{|c|}{ Scales } & \multicolumn{3}{|c|}{ Parameters } \\
\hline $\begin{array}{c}\text { Time } \\
\text { (h) }\end{array}$ & $\begin{array}{l}\text { Space } \\
(\mathrm{m})\end{array}$ & $\begin{array}{c}\mathrm{C}_{\mathrm{ZOO}} \\
\left(\mu \mathrm{g} \mathrm{C} \mathrm{L}^{-1}\right)\end{array}$ & $\underset{\left(\mu \mathrm{g} \mathrm{C} \text { ind }^{-1}\right)}{\mathrm{I}_{\mathrm{M}}}$ & $\begin{array}{c}\text { Chl } a \\
\left(\mu \mathrm{g} \mathrm{Chl} a \mathrm{~L}^{-1}\right)\end{array}$ \\
\hline $4-6$ & 10 & 59 & 70 & 36 \\
\hline $4-6$ & $10^{2}$ & 41 & 67 & 30 \\
\hline 10 & $10^{2}$ & 38 & 81 & 47 \\
\hline $10^{2}$ & $10^{2}$ & 24 & 58 & 12 \\
\hline $10^{2}$ & $10^{4}$ & 18 & 35 & 16 \\
\hline
\end{tabular}

diagram, the highest variability of $\mathrm{C}_{\mathrm{ZOO}}$ was associated with the smallest time scales $(<10 \mathrm{~h}$, and $\approx 10 \mathrm{~m}$; repeated samples and depth interval, $\mathrm{CV} \approx 60)$, decreasing monotonically according as the time and space scales increased. The maximum variability of $\mathrm{I}_{\mathrm{M}}$ took place at time scales of $\approx 10 \mathrm{~h}$ and $10^{2} \mathrm{~m}$, equivalent to day-night changes along the whole water column (vertical migration). For $\mathrm{Chl} a$ the highest variability $(\mathrm{CV} \approx 50)$ was associated with similar time and space scales to those of $\mathrm{I}_{\mathrm{M}}$. The lowest variability for mesozooplankton and chlorophyll occurred at scales of $10^{2} \mathrm{~h}$ (about 4 days, between successive legs) and $10^{4} \mathrm{~m}$, a scale determined by the distance between stations. The variability for IND has not been represented, as it was very similar to that of $\mathrm{C}_{\mathrm{ZOO}}$.

\section{DISCUSSION}

Most of the problems when studying variability in plankton systems arise from difficulties in obtaining synoptic or quasi-synoptic samples in physically unstable environments at the suitable spatial resolution. In the case of zooplankton, the problem is increased by the capacity of most of its components to conduct relatively important movements in the vertical plane which, combined with horizontal shear, can lead to major advection (Steele and Henderson 1992).

Although the resolution of most of the existing sampling techniques for zooplankton is not absolutely satisfactory, it is possible to obtain quantitative zooplankton samples separated into spatial (horizontal or vertical) strata fast enough to be compatible with the rate of change of the community (Donaghay et al. 1992). The displacement velocity of the gravity centre of zooplankton populations ranges from less than $1 \mathrm{~m}$ $\mathrm{h}^{-1}$ to $7 \mathrm{~m} \mathrm{~h}^{-1}$ (Krause and Radach 1989), although for large, fast swimming organisms it can be significantly higher (Enright 1977, Smith at al 1989).

Although Fasham et al (1974) and Fasham (1978) concluded that the spatial variability (patchiness) of plankton cannot be completely apprehended through LHPR hauls, according to Haury (1976a) the samples thus obtained should provide reasonable snapshots of the vertical structure of zooplankton biomass. In our case, the 0-100 m depth layer was sampled in less than $30 \mathrm{~min}$, so the sampling of the different depth strata can be considered as quasi-synoptic.

Regarding the estimates of mesozooplankton biomass through the volume-carbon relationships and volume estimations by semi-automatic image analysis, the method has proven to be reliable. The overall vari- 
ability (CV), including sub-sampling plus individual volume and $\mathrm{C}$ analytical errors, ranges from $9 \%$ to $20 \%$ (Alcaraz et al. 2003, Alcaraz et al. 2010). The obtained values of mesozooplankton carbon $\left(\mathrm{C}_{\mathrm{ZOO}}\right)$ were significantly lower (from $50 \%$ to $75 \%$ ) than previous values obtained by low-pressure reverse-flow water filtration of discrete water volumes in the same area and time of the year (Alcaraz 1980, Alcaraz et al. 1985, Calbet et al. 1996). This is due to the higher retention efficiency of zooplankton organisms by low-pressure filtration methods in comparison with hauling plankton nets with the same mesh-size (Alcaraz 1977). Calbet et al. (2001) obtained similar results when comparing samples taken with a $200-\mu \mathrm{m}$ mesh Juday-Bogorov net with simultaneously obtained microplankton samples that were low-pressure filtered through a $200-\mu \mathrm{m}$ gauze. Further discussions on the problem can be found in Turner (2004), and comments on the sampling bias of the LHPR net in Haury (1973). However, the quantitative underestimation of biomass by oblique plankton hauls should not affect the relative spatial pattern and temporal variability of the extensive properties of zooplankton.

According to the physical structure observed, the three stations corresponded to the typical coastal, frontal and offshore conditions described in Font et al. (1988), Saiz et al. (1992) and Calbet et al. (1996, 2002) for the same area and time of the year. While the coast-offshore gradient in zooplankton biomass was opposed to previous observations (Alcaraz et al. 1994, Calbet et al. 2002), the pattern of vertical distribution at noon repeated the typical deep zooplankton biomass maximum (DZM) associated with the phyto- and chlorophyll deep maximum (Alcaraz 1985, Saiz and Alcaraz 1990). No previous data on organism size allow us to generalize the average larger $\mathrm{I}_{\mathrm{M}}$ of zooplankton organisms associated with the density front, although it agrees with its nature as a nursery area for copepods (Boucher et al. 1987), where euphausiids accumulate and fish larvae are retained (Sabatés and Olivar 1996), thus enlarging the size-range of zooplankton organisms gathered in the area.

The higher variability of zooplankton biomass at small time- and space scales could probably result, as pointed out by Haury (1976a), from the combination of the scale size of zooplankton microstructure with the constant vertical water motion due to internal wave activity. For depth-integrated $\left(10^{2} \mathrm{~m}\right)$ and daynight $(\approx 10 \mathrm{~h}$ ) scales the variability is lower, or of the same order as the values found in single LHPR hauls by Haury (1976b) for organism numbers in the Pacific Central Gyre and the California Current, and the average $I_{M}$ shows the highest variability at the same time and space scales. This finding could be explained by the high number of samplings coinciding with the time of maximum ascension speed at dusk of large, deep zooplankton components, and their descent at dawn. The higher backscatter strength recorded by moored ADCP in the same area and time of the year during the morning and evening migrations of pelagic organisms (Pinot and Jansá 2001), and off Southern California (Smith et al 1989), seem to confirm this hypothesis. In general, the higher variability of $\mathrm{C}_{\mathrm{ZOO}}$ and IND as compared with $\mathrm{Chl} a$ is the consequence of the non-motile nature of most of the phytoplankton components, and of the variability imposed by vertical migration on zooplankton.

Although the spatial-temporal diagram of haul-integrated zooplankton biomass and its variability indicate a persistence of the coast-offshore positive gradient, it also indicates a considerable degree of variability, especially at the front. All the data identify it as a hotspot of zooplankton biomass of larger size, during both day and night. The front is thus an ecotone between hydrographically distinct systems: the Liguro-Provençal-Catalan Current on the coast side, the dome waters offshore and, occluding everything during the summer stratification period, an almost uniform mixing layer, each system having different zooplankton assemblages (Boucher 1984, Calbet et al. 1996).

Further studies in contrasting hydrographic situations (i.e. the winter mixing period or the spring outbreak and autumn collapse of the thermocline) would help to identify the relevant variability scales for extensive properties of the different plankton components and improve the parameterization in plankton production models.

\section{ACKNOWLEDGEMENTS}

We are deeply grateful to Marta Estrada for her friendship, stimulating inspiration and collaboration over almost five decades. This paper is intended as a small homage to her kind and inspired leadership.

The VARIMED-95 cruise took place in the framework of the Spanish research project AMB94-1019 from the Ministry of Science to M. Alcaraz. Financial support was also provided by the projects MAR980854 and CTM2006-12344-c02 to M.A., TOPCOPCTM2011-23480 to E. Saiz and FERMI (CGL201459227-R) to AC and ES. The authors are indebted to all the participants in the VARIMED-95 cruise, and to the crew of the RV Hespérides. This is a contribution of the Marine Zooplankton Ecology Research Group of the Generalitat de Catalunya (2014 SGR 498).

\section{REFERENCES}

Abelló P., Oro D. 1998. Offshore distribution and assemblages of breeding seabirds in the Catalano-Balearic Sea (northwestern Mediterranean). Colonial Waterbirds 21: 422-426.

Acinas S.G., Rodríguez-Valera F., Pedrós-Alió C. 1997. Spatial and temporal variation in marine bacterioplankton diversity as shown by RFLP fingerprinting of PCR amplified 16S rDNA. FEMS Microbiol. Ecol. 24: 27-40. http://dx.doi.org/10.1111/j.1574-6941.1997.tb00420 x

Agawin N.S.R., Agustí S. 1997. Abundance, frequency of dividing cells and growth rates of Synechococcus sp. (cyanobacteria) in the stratified Northwestern Mediterranean Sea. J. Plankton Res. 19: $1599-1615$.

http://dx.doi.org/10.1093/plankt/19.11.1599

Alcaraz M. 1977. Muestreo cuantitativo de zooplancton: análisis comparativo de la eficacia de mangas y botellas en un sistema estuárico. Inv. Pesq., 41: 258-294.

Alcaraz M. 1980. Evolución y distribución vertical de la biomasa de zooplancton expresada en carbono y nitrógeno orgánicos, relación $\mathrm{C} / \mathrm{N}$ y carbono detrítico, en una zona marina afectada por aguas residuales de la ciudad de Barcelona. Inv. Pesq., 44: 265-274. 
Alcaraz M. 1985. Vertical distribution of zooplankton biomass during summer stratification in the Western Mediterranean. In: Gibbs P.E. (ed.), Proceedings of the 19th EMBS. Cambridge Univ. Press, Cambridge, pp. 135-143.

Alcaraz M. 1988. Summer zooplankton metabolism and its relation to primary production in the Western Mediterranean. In: Minas H.J., Nival P. (eds), Océanograaphie pélagique méditeerranéenne. Oceanol. Acta No SP 9, pp. 185-191.

Alcaraz M., Estrada M., Flos J., et al. 1985. Particulate carbon and nitrogen and plankton biomass in oligotrophic and upwelling systems. In: Bas C., Margalef R., Rubies P. (eds), Simposio Internacional sobre las áreas de afloramiento más importantes del Oeste Africano, CSIC, Barcelona: 435-448.

Alcaraz M., Saiz E., Estrada M. 1994. Excretion of ammonia by zooplankton and its potential contribution to nitrogen requirements for primary production in the Catalan Sea (NW Mediterranean). Mar. Biol. 119: 69-76. http://dx.doi.org/10.1007/BF00350108

Alcaraz M., Saiz E., Calbet A., et al. 2003. Estimating zooplankton biomass through image analysis. Mar. Biol. 143: 307-315. http://dx.doi.org/10.1007/s00227-003-1094-8

Alcaraz M., Calbet A., Estrada M., et al.. 2007. Physical control of zooplankton communities in the Catalan Sea. Prog. Oceanogr. 74: 294-312

http://dx.doi.org/10.1016/j.pocean.2007.04.003

Alcaraz M., Almeda R., Calbet A., et al. 2010. The role of arctic zooplankton in biogeochemical cycles: respiration and excretion of ammonia and phosphate during summer. Polar Biol. 33: 1719-1731. http://dx.doi.org/10.1007/s00300-010-0789-9

Boucher J. 1984. Localization of zooplankton populations in the Ligurian marine front: role of ontogenic migration. Deep Sea Res. 31: 469-484. http://dx.doi.org/10.1016/0198-0149(84)90097-9

Boucher J., Ibanez F., Prieur L. 1987. Daily and seasonal variations in the spatial distribution of zooplankton populations in relation to the physical structure in the Ligurian sea front. J. Mar Res. 45: $133-173$. http://dx.doi.org/10.1357/002224087788400891

Calbet A., Alcaraz M., Saiz E., et al. 1996. Planktonic herbivorous food webs in the Catalan Sea (NW Mediterranean): temporal variability and comparison of indices of phyto-zooplankton coupling based in state variables and rate processes. J Plankton Res. 18: 2329-2347.

Calbet A., Garrido S., Saiz E., et al. 2001. Annual zooplankton succession in coastal NW Mediterranean waters: the importance of the smaller size fractions. J. Plankton Res. 23: 319-331.

Calbet A., Saiz E., Alcaraz M. 2002. Copepod eggproduction in the NW Mediterranean: effects of winter environmental conditions. Mar. Ecol. Prog. Ser. 273: 173.184

Donaghay P.L., Rines H.M., Sieburt J.McN.. et al. 1992. Simultaneous sampling of fine scale biological, chemical and physical structure in stratifed waters. Arch. Hydrobiol. Beih. 36: 97-108.

Enright J.T. 1977. Copepods in a hurry: sustained high-speed upward migration. Limnol. Oceanogr. 22: 118-125.

Estrada M. 1985. Deep phytoplankton and chlorophyll maxima in the Western Mediterranean. In: Moraitou-Apostoulou M., Kiortsis V. (eds), Mediterranean marine ecosystems. Plenum Press, New York, pp. 247-277.

Estrada, M. 1996. Primary production in the northwestern Mediterranean. Sci. Mar. 60: 55-64

Estrada M., Margalef R. 1988. Supply of nutrients to the Mediterranean photic zone along a persistent front. In: Minas H.J., Nival P. (eds), Océanographie pélagique méditerranéenne, Oceanol. Acta N ${ }^{\circ}$ SP 9: 133-142.

Fasham M.J.R. 1978. The statistical and mathematical analysis of plankton patchiness. Oceanogr. Mar. Biol. Ann. Rev. 16: 43-79.

Fasham M.J.R., Angel M.V., Roe S.J. 1974. An investigation of the spatial pattern of zooplankton using the Longhurst-Hardy plankton recorder. J. Exp. Mar. Biol. Ecol. 16: 93-112.

Fernández de Puelles M.L., Valencia J., Jansá J., et al. 2004. Hydrographical characteristics and zooplankton distribution in the Mallorca channel (Western Mediterranean): spring 2001. ICES J. Mar. Sci. 61: 654-666.

Font J., Salat J., Tintoré J. 1988. Permanent features of the circulation in the Catalan sea. In: Minas H.J., Nival P. (eds), Pelagic
Mediterranean oceanography. Oceanol. Acta, 9: 51-57.

Haury L.R. 1973. Sampling biass of a Longhurst-Hardy Plankton Recorder. Limnol. Oceanogr. 18: 500-506.

Haury L.R. 1976a. Small-scale pattern of a California current zooplankton assemblage. Mar. Biol. 37: 137-155. http://dx.doi.org/10.1007/BF00389124

Haury L.R. 1976b. A comparison of zooplankton patterns in the California current and North Pacific Central Gyre. Mar. Biol. 37: $159-167$ http://dx.doi.org/10.1007/BF00389125

Haury L.R., Mc Gowan J.A., Wiebe P.H. 1978. Patterns and processes in the time-space scales of plankton distributions. In: Steele J.H. (ed.), Spatial pattern on plankton communities. Plenum Press, NY, pp. 277-327. http://dx.doi.org/10.1007/978-1-4899-2195-6 12

Krause M., Radach G. 1989. On the relations of vertical distribution, diurnal migration and nutritional state of herbivorous zooplankton in the northern North Sea during FLEX 1976. Int. Revue ges. Hydrobiol. 74: 371-417.

Longhurst A.R., Reith A.D., Bower R.E., et al. 1966. A new system for the collection of multiple serial plankton samples. Deep Sea Res. 13: 213-222. http://dx.doi.org/10.1016/0011-7471(66)91101-6

Mazzocchi M.G., Siokou I., Tirelli V., et al. 2014. Regional and seasonal characteristics of epipelagic mesozooplankton in the Mediterranean Sea based on an artificial neural network analysis. J. Mar. Syst. 135: 64-80. http://dx.doi.org/10.1016/j.jmarsys.2013.04.009

Pinot J.M., Jansá J. 2001. Time variability of acoustic backscatter from zooplankton in the Ibiza channel (western Mediterranean). Deep Sea Res. 48: 1651-1670. http://dx.doi.org/10.1016/S0967-0637(00)00095-9

Sabatés A., Olivar P. 1996. Variation of larval fish distributions associated with variability in the location of a shelf-slope front. Mar. Ecol. Prog. Ser. 135: 11-20. http://dx.doi.org/10.3354/meps 135011

Saiz E., Alcaraz M. 1990. Pigment gut contents of copepods and deep phytoplankton maximum in the Western Mediterranean. J Plankton Res. 12: 665-672. http://dx.doi.org/10.1093/plankt/12.3.665

Saiz E., Rodriguez V., Alcaraz M. 1992. Spatial distribution and feeding rates of Centropages typicus in relation to frontal structures in the Catalan Sea (Western Mediterranean). Mar. Biol. 112: $49-56$ http://dx.doi.org/10.1007/BF00349727

Saiz E., Calbet A., Trepat I., et al. 1997. Food availability as a potential source of bias on the egg production method for copepods. J. Plankton Res. 19: 1-14. http://dx.doi.org/10.1093/plankt/19.1.1

Salat J. 1996. Review of hydrographic environmental factors that may influence anchovy habitats in northwestern Mediterraneaan. Sci. Mar. 60: 21-32.

Smith P.E., Ohman M.D., Eber L.E. 1989. Analysis of the patterns of distribution of zooplankton aggregations from an accoustic doppler current profiler. CalCOFI Rep. 30: 88-103.

Stavn R.H. 1971. The horizontal-vertical distribution hypothesis: Langmuir circulations and Daphnia distributions. Limnol. Oceanogr. 16: 453-446. http://dx.doi.org/10.4319/1o.1971.16.2.0453

Steele J.H., Henderson E.W. 1992. A simple model for plankton patchiness. J. Plankton Res. 14: 1397-1403. http://dx.doi.org/10.1093/plankt/14.10.1397

Stommel H. 1963. Varieties of oceanographic experience. Science 139: $572-576$. http://dx.doi.org/10.1126/science.139.3555.572

Turner J.T. 2004. The importance of small planktonic copepods and their roles in pelagic marine food webs. Zool. Stud. 43: 255-266.

Vance T.C., Doel R.E. 2010. Graphical methods and cold war scientific practice: the Stommel diagram's intriguing journey from the physical to the biological sciences. Hist. Stud. Nat. Sci. 40: 1-47. http://dx.doi.org/10.1525/hsns.2010.40.1.1

Winsor C.P., Clarke G.L. 1940. A statistical study of variation in the catch of plankton nets. J. Mar. Res. 3: 1-34.

Yentsch C.S., Menzel D.W. 1963. A method for the determination of phytoplankton chlorophyll and pheophytin by fluorescence. Deep Sea Res. 10: 221-231. 